\title{
GPR32 wt Allele
}

National Cancer Institute

\section{Source}

National Cancer Institute. GPR32 wt Allele. NCI Thesaurus. Code C51457.

Human GPR32 wild-type allele is located in the vicinity of $19 q 13.3$ and is approximately 1 kb in length. This allele, which encodes probable G-protein coupled receptor 32 protein, plays a role in G-protein coupled receptor signal transduction and may be involved in chemotaxis. 